\title{
Editorial: The Sitz im Leben of a Public Theology
}

The globalization of a public theology raises fresh questions for the practice of the discipline. It must of necessity let attention fall on matters to do with setting, context, or situations in life - in other words, the Sitz im Leben of particular expressions of a public theology. These things are not the same from one part of the world to another, one period in time to another. This edition of the International Journal of Public Theology represents an invitation to consider how advocates and practitioners of a public theology engage with such diverse settings. There are implications for how the discipline might then move away from generalized statements to do with its glocalization and delve deeper into how the public space is understood in actual locations. How are the relationships between theory and practice being enacted? What are the lines of engagement between the academy and congregations in the service of specific causes?

For Emanuel Gerrit Singgih the immediate setting for his public theology lies in the relationship of Christians and Muslims in the Panacasila understanding of the state in Indonesia. The toleration that has been espoused (expressed through the 'freedom of religion from public spaces') under President Soekarno at the foundation of the newly independent country was placed under pressure through the campaign run for the Governorship of the city of Jakarta by Ahok. The prior history had been one where 'nationality was placed above religion'. Muslims and the Christian minority had developed their own respective public theologies around a vision for the nation. The controversy surrounding Ahok's candidature and the ambiguous response of President Joko Widodo coincided with a conservative turn within Islam in Indonesia. It led to alternative public theologies for both religions established on the affirmation of identity. In a rather surprising way Santa hats and Christmas observances became sites of a contested public space. Radical Islamists pronounced a fatwa against Ahok.

This political, cultural and religious fracture could be read from any one of several different perspectives. Singgih's particular interest lay in a rendering of what he termed a pluralist public theology. Here he drew upon the work of Indian public theologies like those of Wilfred Felix and Peniel Rajkumar in order to extend the account of the public space identified by Sebastian Kim in his Theology in the Public Sphere. The difference Singgih discerned was the need to engage with and respond to a Muslim public theology—which was 
the dominant theology - in the public domain. Singgih concluded that there is benefit in situating a Christian public theology alongside others in a pluralist setting. In the case of Indonesia it allows for the possibility of a Christian public theology to be transformed beyond a theology of identity into one which can address the weak points in the outworking of Ahok's political agenda. Being specific that meant a Christian public theology should demonstrate a liberative concern for the poor who tend to be Muslim.

This desire to reframe the space in which a public theology operates is also the aim of Chammah Kaunda writing out of Zambia. In this case the overriding intention can be seen as two-fold. The major aim was to decolonize public theology alongside a secondary intention of making use of empirical primary sources. Kaunda is responding to a particular problem. The task of decolonizing a public theology is due to the way in which Zambia had declared itself to be a Christian nation and how that confession was then interpreted and exploited by a presidential candidate in the 2016 elections. Kaunda cites evidence to support the claim that the successful candidate Edgar Chagwa Lungu is a 'drunkard'. He was nevertheless able to secure the support of the Pentecostal-Charismatic traditions in Zambia which are committed to the principle of the country being a Christian nation. In Zambia for that support to be granted there needed to be plausible evidence of his Christian credentials-hence emerges Kaunda's need to decolonize the regnant theology at work in the public spaces of his country. To this end Kaunda delivers a mild rebuke to those public theologians who confine themselves to the academic setting of ideology and theory. His original submission was replete with a large number of coloured photographs taken from social media which repeatedly showed Lungu with church leaders, on his knees and at worship. Kaunda supported his argument with regards to Lungu and the necessity of a president perceived to be Christian with interviews with church leaders. In the background here lies the work Mark Cartledge has done on empirical research and 'ordinary theology'.

Kaunda took Nico Koopman as his example of a public theology that failed to make sufficient use of empirical primary research. Koopman he conceded is 'an outstanding South African public theologian'. It is the second time in as many issues that Koopman has found himself on the receiving end of those who wish to alter aspects of the discourse surrounding a public theology. In this edition Koopman makes a veiled response to Jakub Urbaniak's argument that the 'prevalent discourses that have developed in South Africa under the umbrella of public theology since the mid-199os' have failed to explain 'why liberation theologies—be it black, feminist or queer-may and should constructively 
disrupt these discourses'. ${ }^{1}$ This reading of his work has allowed Koopman to consider his collected works over an extended period of time and to do so at a time 'when democracy seems to fail'. The democracy that Koopman has in mind, of course, is the 'young South African' version of the twenty-five years post-apartheid. It is, nevertheless, part of a much larger global concern that expresses itself through an increasing number of references to the 'twilight of democracy' and many of its associated virtues like those of tolerance and compassion. Koopman is not unaware of this much larger horizon and draws upon the work of the French philosopher Jacques Rancière, the theologian Peter Hodgson and, most powerfully, the Brazilian social scientist and Reformed theologian, Rubem Alves to that end. Koopman is familiar with the critiques levelled at the democratic system in South Africa. What he sets out to do is both critique and envision what a public theology has been and might be in the midst of this changing political and cultural Sitz im Leben. For that purpose he revisits the 'approaches' to a public theology that he has found in the past grounded in the three-fold office of Christ - the royal, the priestly, and the prophetic. In the current situation Koopman argues that the prophetic must take priority, though not to the total exclusion of the other two. The purpose of this prophetic public theology is to critique that which prevents the envisioning and putting into policy those things which make for reconciliation, justice and liberation, especially for those who are most vulnerable. From Alves Koopman has sought to effect a bridge between theologies and campaigns that somehow 'forgot the vision of a liberated society' and the need for its envisioning again and to do so when the passage of time has led to hope's disappointment.

The theological emphases to do with Christology and the Trinity that Koopman employs sound an echo within Caroline Redick's desire to make a home for refugees. The argument she makes is bound to Jürgen Moltmann's account of the Trinity. Redick concedes that this strategy of dealing with the contemporary refugee crisis may seem strange. This doctrine is often looked upon as being speculative and seems to be removed from the desperate plight of Syrian refugees in recent years. Of particular significance for her is Moltmann's understanding of the Persons of the Trinity being seen as 'spaces' which allows for 'the risk of love' and 'the possibility of death'. It is a dialectic of (in)dwelling, living space and relationality that lends itself to a notion and Christian ethic of hospitality. Redick privileges the 'wandering Shekinah' of God's Spirit with the homeless wanderings and displacement of the people of Israel in exile.

1 Jakub Urbaniak, 'Elitist, Populist or Prophetic? A Critique of Public Theologising in Democratic South Africa', International Journal of Public Theology, 12:3-4, (2018), 332-52 at $33^{2}$. 
The 'porous boundaries' among the three Persons of the Trinity itself furnish a model for risk in the face of fear and the enfolding of welcome. Through Moltmann's distinctive theology of the Trinity Redick is intimating an alternative to walls, hard line policies and venomous tweets that caricature and falsely represent those whose lives are in flight, seeking a home.

Kaunda's concern for empirical research within the practice of a public theology is shared by Mark Dawson. The issues at stake surround the mainstreaming of Fair Trade. The core assumption is that the Fair Trade movement was indebted to a Christian theology along with the resources of local congregations at its inception. It offered an alternative to the more normal ways of the competitive market based on profit and advantage. It was not necessarily designed for the business world of supermarkets and other overtly commercial enterprises insofar as it strove for fairness (obviously) and a just return for the often highly vulnerable and impoverished provider. Dawson draws upon an extensive sequence of interviews in order to show how members of local congregations and church agencies have valued the work and intention of Fair Trade. What is notable about Dawson's argument is the claim that Fair Trade is a form of public theology and provides public theologians with a vehicle to inform better congregations as to what a public theology is. In the midst of the mainstreaming of Fair Trade it is time to recover this dimension to its work.

This rather practical focus to a public theology is also captured by Robert van Putten, Ronald van Steden and Patrick Overeem. Their interest lies in what they refer to as a post-secular public administration. They draw upon Jürgen Habermas' idea of the 'post-secular turn' in society to describe the setting for which they are writing: it can no longer be adequately defined in terms of the secularization hypothesis despite the practice of professional public administrators - theorists and practitioners - to the contrary. Using Habermas van Putten et al. make the case for the inclusion of religious beliefs and ideas and the perspectives of minority cultures. They do so on the basis that such should be welcomed by those who are non-religious in much the same way as a reciprocal relationship the other way can be affirmed. Their subsequent empirical research revolves around the work of night-time street pastors in Cardiff. The work which these pastors do in 'mellowing down' potentially fraught situations is an example of how faith-based, civil society organizations can contribute to the well-being and good of a city. In the post-secular society they are able to live out both a personal and a public faith in a way that is relatively anonymous.

\section{Clive Pearson}

Editor-in-chief 